\title{
PRELIMINARY STUDIES ON EXTENSION OF THE SHELFLIFE OF PITO
}

\author{
W.O. Ellis, I. Oduro and D.M. Terkuu \\ Department of Biochemistry and Biotechnology, \\ Kwame Nkrumah University of Science and Technology, Kumasi, Ghana
}

\begin{abstract}
Alcoholic sorghum malt beverage, pito is a popular drink in Ghana, however it has a short shelflife of two days. In an attempt to extend its shelflife a study was carried out using malted sorghum. This was milled, mashed by single decoction and fermented by both lactic and ethanolic fermentation by resident microbes and pito wild yeast. The resulting product, pito was treated in two ways, first it was bottled, sodium metabisulphite added and pasteurized, this was coded PI. The second treatment involved filtration of yeast cells and pasteurization, this was coded NI. Bottled samples were stored for 2 months and analysis carried out on samples. Parameters monitored were pH, colour, specific gravity, alcohol content, degree of fermentation, extract content and energy. Sensory evaluation was also carried out on the samples. Results showed that pito can be processed, bottled and stored for about 2 months using one of the 2 treatments. However, the treatment involving PL. ivas more efficient. Sensory results showed that the products were acceptable to the panelists.
\end{abstract}

Keywords: Pito, sorghum, shelflife, sensory evaluation

\section{INTRODUCTION}

The popularity of products from the conversion of sugars into ethanol by yeast is almost universal and there is hardly a culture without its own indigenous alcoholic beverage. The sw material base varies from one country to another. Barley is used in Egypt, rice in Asia, corn in the Americas and wheat in Europe. Africa has a number of traditional beers; Sudan's Merissa, Pombe from East Africa and the Cameroon has Amgba and Affouk. In Nigeria and Northern parts of Ghana, the local beer brewed is Pito (Adam, 1995).

Pito is produced from local cereals such as maize, sorghum or millet and some of these are produced on a substantial scalc. Pito production is the result of mixed lactic/ethanolic fermentation and bears little resemblance to Europeanstyle beer (Adam, 1995). Pito is not hopped and subjected to souring resident microorganisms prior to ethanolic fermentation. This whole process was adopted by the indigenous people of the Dagaaba traditional area to brew alcoholic beverage from sorghum and later other cereals like maize and millet. This process, modified with time has not reccived much scientific attention and modification in terms of preservation and packaging to extend the shelflife. The study was thus carried out to extend the shelfifife of pito.

\section{MATERIALS AND METHODS}

Source of Raw Material

Red to white colour sorghum was obtained from the Lawra Market in the Upper West Region of 
Ghana. This variety was of the carly maturing typc.

\section{Proximate Analysis on Sorghum and Malted Sorghum}

The percentage moisture, ash, crude fibre, crude fat, crude protein and carbohydrate of the raw sorghum and malted sorghum were determined based on the Official Methods of Analysis $(A O A C, 1990)$. All analysis were done in triplicatc.

\section{Pito Production}

The method used was based on the Dagaaba tribal art of brewing pito in the Upper West Region of Ghana. Thirty kilogram of sorghum was cleaned and soaked in water for 2 days (48 hours). The steeping liquor was changed every 12 hours to prevent the development of odour. The soaked sorghum grains were spread and allowed to germinate for 4 days in reed basket. The grains were moistened as often as considcred necessary. On the fourth day, the green malt were tightly packed into a nylon sack and allowed to ferment. The green malt was then sun dried and the dried malt coarse-milled together with the shoots and roots. The milled malt was mixed with about 15 litres of water followed by a litre of slimmy solution made out of dried okro stems to speed up the sedimentation of the coarse particles. The clear supernatant, which contains enzymes, was decanted and the coarse particle portion boiled at $90^{\circ} \mathrm{C}$ for 30 minutes to gelatinize. The supernatant was then mixed with the boiled coarse particles to attain a temperature of $60^{\circ} \mathrm{C}$. The mixture was allowed to undergo lactic acid fermentation (souring) by resident micro organisms (lactic acid bacteria) for 17 hours and then filtered to remove the coarse particles. The wort obtained was boiled to evaporate excess water. The concentrated wort was cooled to room temperature and the $\mathrm{pH}$ measured with a Corning $\mathrm{pH}$ meter. It was then pitched with the yeast and allowed to ferment for 15 hours. The resultant product, pito was cooled to $15^{\circ} \mathrm{C}$ to coagulate the yeast, and then filtered to remove the yeast and other particles. The pito obtained was subjected to two treatment methods of preservation. For the first treatment, a 5-litre portion of the pito was pasteurized between $60-70^{\circ} \mathrm{C}$, for 15 minutes, cooled to a temperature of $-1^{\circ} \mathrm{C}$ and then packaged in bottles under carbonation. The bottled ptio were then pasteurized and coded NL. For the second treatment, another 5-litre portion was subjected to the same treatment, but $\mathrm{Na}_{2} \mathrm{~S}_{2} \mathrm{O}_{5}$ was added and coded PL. The products were then store for two months under ambient conditions.

\section{Analysis Performed on Pito}

Analyses were carricd on the freshly prepared pito and the samples stored for 2 months using the 2 treatment methods. Analysis was done using the automated beer analyzer equipment (Beer Analyzer Z, software version, V4 509. Anton Paar GmbH Company, A - 8054 Graz/ Austria - Europe). The parameters monitored were: specific gravity, real extract, $(\% \mathrm{w} / \mathrm{w})$, alcohol $(\% \mathrm{v} / \mathrm{v})$, original extract $(\% \mathrm{w} / \mathrm{w})$, apparent degree of fermentation (\%), apparent extract (Plato) and calories $(\mathrm{kal} / 100 \mathrm{ml})$. Other parameters were; $\mathrm{pH}$ using the Coming $\mathrm{pH}$ meter and colour by spectrophotometry. For colour determination, $10 \mathrm{ml}$ of the pito was added to $90 \mathrm{ml}$ of distilled water and the absorbance read at $430 \mathrm{~nm}$ wavelength. The colour was calculated using the formula below:

$$
\text { Colour }=\alpha \times 10 \text { (D.F) } \times 25 \text {, }
$$

where

$$
\begin{aligned}
& \alpha=\text { absorbance } \\
& D . F=\text { dilution factor } \\
& 10 \text { and } 25 \text { are fixed values - constants } \\
& \text { (path length) }
\end{aligned}
$$

\section{Sensory Analysis of Pito}

Sensory analysis using the Freidman's Rank Test was carried out with 20 panelists who were normal pito consumers. A 5-point hedonic scale ranging from like very much (1) to dislike very much (5) was used in the analysis. Five pito 
samples, freshly brewed (day 0), 1 week old, 2 weeks old, 4 months old and 8 months old were evaluated. The parameters monitored were taste, aroma, colour and alcohol content.

\section{Statistical Analysis}

Statistical analysis (ANOVA) was carried out on the data obtained using the Microsoft Excel Program. The least significant difference was computed at $\mathrm{p}<0.05$.

\section{RESULTS AND DISCUSSION}

Tables 1, 2 and 3 show the results of the study. In brewing, the interest of the maltster and brewer are mostly centered on the protein and carbohydrate content of the grain and the diastatic power of the malt. The results of the proximate analysis (Table 1) shows that the moisture content of the sorghum and malted sorghum were $10.8 \%$ and $9.7 \%$ respectively. Grain moisture content of less than $14 \%$ is required for malting purposes. Above this level perceptible respiration of the grain in storage releases moisture and causes germination in storage. The heat build up kills the embryo which cannot then be malted (Lewis and Young, 1995). Thus the moisture content of the sorghum grains is adequate for better storage and can be used for malting. The low moisture level of the malted sorghum enhances longer storage and prevention of mold growth.

The sorghum and malted sorghum contained carbohydrate levels of $72.1 \%$ and $60 \%$ respectively (Table 1). Kent (1983) reported carbohydrate content of sorghum to be $79.7 \%$. The variation may be due to varietal differences. The raw grains had relatively higher carbohydrate content than the malted grains and the difference may be due to the fact during germination some residual starch are degraded mainly to polyglucose. During malting about $15-18 \%$ of starch endosperm is solubilized and of this level, $4-6 \%$ is converted to simple sugars and dextrin which give body to the beer (Lewis and Young, 1995). The protein contents of the sorghum grains (10.72\%) and malted sorghum $(12.50 \%)$ were lower than reported values. Kent (1983) gave the prote content of sorghum as $12.4 \%$ while Briggs (1998) reported that for malted sorghum as $12.9 \%$. During germination, some proteins are activated while others are involved in hydrolysis. However, some of the nitrogenous compounds are used to build up proteins of the rootlets (Hough, 1996). This may account for the variation in the protein content between the malted and unmalted sorghum (Table 1).

Table 1: Proximate Analysis results on Sorghum samples

\begin{tabular}{lcc}
\hline Parameters & $\begin{array}{c}\text { Raw } \\
\text { Sorghum }\end{array}$ & $\begin{array}{c}\text { Malted } \\
\text { sorghum }\end{array}$ \\
\hline Moisture (\%) & $10.80(0.18)$ & $9.70(0.21)$ \\
Ash (\%) & $1.30(0.15)$ & $1.60(0.00)$ \\
Crude fat (\%) & $3.00(0.03)$ & $3.70(0.01)$ \\
Crude fibre (\%) & $2.00(0.04)$ & $12.50(0.01)$ \\
Crude protein (\%) & $10.72(0.14)$ & $12.50(0.00)$ \\
Carbohydrate (\%) & $72.10(0.01)$ & $60.00(0.02)$ \\
\hline
\end{tabular}

Specific gravity (SG) which reflects the strength of the pito was 1.038 for PL and 1.039 for NL at day 0 . However, this reduced to 1.028 and 1.026 respectively after two months of storage (Table 2 ). The slight reduction may be due to the conversion of the residual carbohydrate to alcohol. This is shown by the significant increase in alcohol content from 2.3 to $3.9 \%$ (v/v) for PL and 2.4 to $4.3 \%(\mathrm{v} / \mathrm{v})$ for NL (Table 2). The relatively high increase in alcohol content for NL compared to PL may be attributed to the degree of effectiveness of the preservation method applied in each treatment. Even though the values obtained show that the application of sodium metabisulphite in PL was relatively effective compared to the normal pasteurization both methods were not highly effective in preventing secondary fermentation caused by residual yeasts and enzymes.

Generally for good beer production in the brew- 
Table 2: Results on the Quality of Pito

\begin{tabular}{lcccc}
\hline \multicolumn{1}{c}{ Parameters } & $\begin{array}{c}\text { Day Zero } \\
\text { PL }\end{array}$ & $\begin{array}{c}\text { Two Months } \\
\text { NL }\end{array}$ & PL & NL \\
\hline $\mathrm{pH}$ & $3.40 \pm 0.03$ & $3.40 \pm 0.01$ & $3.30 \pm 0.03$ & $3.40 \pm 0.01$ \\
Colour (EBC) & $77.00 \pm 0.00$ & $77.00 \pm 0.00$ & $82.50 \pm 0.00$ & $82.50 \pm 0.00$ \\
Specific gravity & $1.038 \pm 0.00$ & $1.039 \pm 0.00$ & $1.028 \pm 0.00$ & $1.026 \pm 0.00$ \\
Alcohol (\% v/v) & $2.30 \pm 0.01$ & $2.40 \pm 0.01$ & $3.90 \pm 0.01$ & $4.30 \pm 0.01$ \\
Real extract (\%w/w) & $10.24 \pm 0.01$ & $10.45 \pm 0.01$ & $8.46 \pm 0.01$ & $8.14 \pm 0.01$ \\
Original extract (\%w/w) & $13.61 \pm 0.03$ & $13.95 \pm 0.03$ & $14.25 \pm 0.03$ & $14.52 \pm 0.03$ \\
Apparent degree of Fer- & $30.31 \pm 0.03$ & $30.68 \pm 0.03$ & $50.07 \pm 0.03$ & $54.17 \pm 0.03$ \\
mentation (\%) & & & & \\
Apparent extract ( ${ }^{\circ}$ plato) & $9.44 \pm 0.00$ & $9.67 \pm 0.00$ & $7.11 \pm 0.01$ & $6.65 \pm 0.00$ \\
Energy (Kcal/100ml) & $49.86 \pm 0.05$ & $50.15 \pm 0.05$ & $52.12 \pm 0.05$ & $53.12 \pm 0.05$ \\
\hline
\end{tabular}

$\mathrm{NL}=$ preserved by pasteurization at $60-70^{\circ} \mathrm{C}$ for 30 minutes

$\mathrm{PL}=$ preserved by pasteurization and chemical preservation

ery industry, the total nutrient of the wort prior to fermentation (which is referred to as percent original extraction (OE)) must be about $11.3 \%$. However, in this study the OE was $13.61 \%$ for PL and $13.95 \%$ for NL at day 0 (Table 2). 'These values were high and needed to be reduced by dilution to enable the medium sustain the yeast. $\mathrm{OE}$ (original extract) is directly related to specific gravity such that the higher the $\mathrm{OE}$, the higher the SG. The extent of fermentation of the pito samples increased with storage time. This is shown by the Apparent Degree of Fermentation $(\mathrm{ADF})$. The $\mathrm{ADF}$ at day 0 was $30.31 \%$ for $\mathrm{PL}$ and $30.68 \%$ for NL. After 2 months, the ADF increased to $50.07 \%$ and $54.17 \%$ respectively (Table 2). The increase indicates the conversion of some residual sugars in the pito samples to alcohol. Acceptable ADF levels for beer produc- tion in the brewery industry are usually $70 \%$ and above since this level results in alcohol production of 5\% (v/v) and above. However, the levels recorded were below $70 \%$ for both samples at day 0 and after 2 months indicating that alcohol content of the pito would be very low (below $5 \%)$.

The level of residual sugars and the degree of fermentation or completion level is shown by the Apparent Extract (AE) value and the percent Real Extract (RE) value. The AE gives a measure of the residual nutrients (mainly sugars) during the course of fermentation while the RE is a measure of the alcohol during the fermentation process. The pito samples gave very high $\mathrm{AE}$ values of 9.44 and $9.67^{\circ}$ Plato for PL and NL at day 0 . These values decreased to 6.65 and 7.11 
${ }^{\circ}$ Plato for NL and PL respectively after 2 months indicating that the residual sugars have been utilized as a result of secondary fermentation (Lewis and Young, 1995). A similar trend was observed with the percent $R E$ values. The extent of decrease was from $10.24 \%$ at day 0 to $8.46 \%$ after 2 months for PL and $10.45 \%$ to $8.14 \%$ for NL (Table 2). These values indicate that secondary fermentation was on-going in the pito samples. Generally, an RE value of $3 \%$ and below indicates that fermentation is about completing and an $\mathrm{AE}$ value of $3^{\circ} \mathrm{Plato}$ or below is the acceptable level.

Table 3: Sensory results of stored Pito samples

\begin{tabular}{lcc}
\hline $\begin{array}{c}\text { Age of } \\
\text { product }\end{array}$ & \multicolumn{2}{c}{ Overall Acceptability } \\
\hline Day zero & $2.0 \pm 0.00$ & NL \\
1 week & $2.0 \pm 0.00$ & $1.5 \pm 0.00$ \\
2 weeks & $2.0 \pm 0.01$ & $1.5 \pm 0.00$ \\
1 month & $1.7 \pm 0.02$ & $1.0 \pm 0.02$ \\
2 months & $2.1 \pm 0.02$ & $1.5 \pm 0.00$ \\
\hline
\end{tabular}

$\mathrm{NL}=$ preserved by pasteurization at $60-70^{\circ} \mathrm{C}$ for 30 minutes $\mathrm{PL}=$ preserved by pasteurization and chemical preservation

There was no change in the $\mathrm{pH}$ of the pito sample with storage time. However, colour of the samples increased from $77 \mathrm{EBC}$ units to 82.5 EBC units. The increase may be due to the oxidation of tannins (Lewis and Young, 1995) within the pito samples. The results of the sensory analysis showed that the overall acceptability varied to different extents for the pito products stored for different periods by the panelists (Table 3). Statistical analysis of the data obtained showed that for each of the storage periods, panelists' response for the two products for cach parameter monitored were significantly different $(p<0.05)$. The observed data (Table 3$)$ shows that preference was more for the NL samples relative to that of the PL samples. On the whole, overall preference was for the one month NL stored products compared to the stored products.

\section{CONCLUSION}

The results of this study show that even though the treatments used were not highly efficient, it showed that pito could be preserved and stored for eight weeks. The sensory results show that treatment using only pasteurization was more preferred by consumers. Thus, the potential to process and bottle pito for storage and ultimate sale to consumers is possible.

\section{REFERENCES}

Adams, M.R. and Moss, M.O. (1995). Food Microbiology. The Royal Society of Chemistry; U.K. pp. 442-445.

AOAC (1990). Official Methods of Analysis, Association of Official Analytical Chemists. $5^{\text {th }}$ Edition. Virginia, USA.

Briggs, D. E. (1998) Malts and malting. Blackie Academic and Professionals, London, UK.

Hough, J. S. (1996). The biotechnology of malting and brewing. $2^{\text {nd }}$ edition. Cambrigde University Press, Britain. Pp. 26-31

Kent, N. L. (1983) Technology of cereals. $3^{\text {rd }}$ edition. Pergamon Press. Oxford, UK.

Lewis, M.J. and Young, T.W. (1995). Brewing. $1^{\text {st }}$ Edition. Chapman and Hall. Page Bros., Norwick, Britain. pp. 209-210.

Manual - Beer Analyzer (1993). Anton Paar GmBH Company, Austria. 